\title{
Upper Miocene Megavolcano in the Lesser Caucasus, Georgia-Turkish Border: Geological and Isotope evidences
}

\author{
A. OKROSTSVARIDZE ${ }^{1 *}$, I. GAMKRELIDZE $^{2}$, \\ G. BOICHENKO ${ }^{1}$, I. SKHIRTLADZE ${ }^{1}$ \\ ${ }^{1}$ Institute of Earth Sciences, Ilia state University, Tbilisi \\ 0162, Georgia (*correspondence: \\ okrostsvari@gmail.com) \\ ${ }^{2}$ Department of Earth Sciences Georgian Nation Academy of \\ Sciences, Tbilisi 0108, Georgia
}

One of the best examples of postcollisional volcanic activities in Lesser Caucasus and particularly in SamthkheJavakheti region (southern Georgia), is represented by thick repetitive layers (up to $\sim 1 \mathrm{~km}$ ) of so called Goderdzi formation, composed by mostly andesitic-dacitic pyroclastic material and lava flows. These volcanogenic material are best exposed in river valleys cutting across the region. Good example is the Mtkvari river canyon. Here, the lower part of the Goderdzi formation consists of ignimbrites, large volcanic breccia and airborne ash layers. The thicknesses of ignimbrites $(60-80 \mathrm{~m})$ and ash $(\sim 3 \mathrm{~m})$ are quite remarkcable. We believe that the relic of this volcano is a caldera located in the present day Niala valley $(15 \times 20 \mathrm{~km})$, which is injected by post-volcanic andesitic domes.

Volcanic ashes of similar petrographic charachteristics (main constituents are hornblende, pyroxene and volcanic glass) are also observed in remote parts of intermountain depression of Georgia and Azerbaijan in form of the Late Miocene marine sedimet interlayers. Thickness of the ash layers varies between several decimeters to about $5 \mathrm{~m}$, and generally decreases to the east. Due to such similarities, these ashes were considered to have common source. This assumption is further confirmed by our latest $\mathrm{U}-\mathrm{Pb}$ dating of zircons from the Mtkvary river canyon ignimbrites, which were erupted together with, but deposited earlier then airborne ash. Samples were taken from three parts of the ignimbrites and 72 zircons were dated. The results are the following: $13 \mathrm{GEO}-04=7.50 \pm 0.42 \mathrm{Ma} ; 13 \mathrm{GEO}-05=7.54 \pm 0.21$ Ma; 13GEO-06=7.52 $\pm 0.21 \mathrm{Ma}$. Thus, the age of ignimbrites are $7.5 \mathrm{Ma}$ and coinsides with the ages of ash from intrmountain depression. The age correlation and similar petrographic features, together with considerable thickness suggests that the eruptions were strong enough to produce huge volume of pyroclastic material. However, the volcanic explosivity index (VEI) is still unestablished and requires further work. 